\title{
Effect of okra plant resistance on transmission rate of okra enation leaf curl virus by its vector whitefly, Bemisia tabaci
}

\section{E. Pasupathi*}

Department of Agricultural Entomology, Agricultural College and Research Institute, Tamil Nadu Agricultural University, Madurai - 625104 (Tamil Nadu), India

\section{Murugan}

Department of Agricultural Entomology, Tamil Nadu Agricultural University, Coimbatore - 641003 (Tamil Nadu), India

\section{Chinniah}

Department of Agricultural Entomology, Agricultural College and Research Institute, Tamil Nadu Agricultural University, Madurai-625104 (Tamil Nadu), India

\section{J. Ramalingam}

Department of Plant Biotechnology, Tamil Nadu Agricultural University, Coimbatore - 641003 (Tamil Nadu), India

\section{G. Karthikeyan}

Department of Plant Pathology, Tamil Nadu Agricultural University, Coimbatore - 641003 (Tamil Nadu), India

\section{S. Harish}

Department of Plant Pathology, Tamil Nadu Agricultural University, Coimbatore - 641003 (Tamil Nadu), India

${ }^{*}$ Corresponding author. Email: pasupathi441@gmail.com

\section{How to Cite}

Pasupathi, E. et al. (2021). Effect of okra plant resistance on transmission rate of okra enation leaf curl virus by its vector whitefly, Bemisia tabaci. Journal of Applied and Natural Science, 13 (SI), 63 - 68. https://doi.org/10.31018/jans.v13iSI.2778

\begin{abstract}
The present study aimed to investigate the effect of age of the okra plants that showed varying whitefly resistance responses on the transmission rate of okra enation leaf curl virus (OELCV) by its vector whitefly Bemisia tabaci. The OELCV infected whitefly adults were collected from whitefly colonies and were challenged on the test okra accessions (Upl mona 2, Co 1, Arka anamika and $\mathrm{AE}$ 64) of differential ages which were individually caged (7, 10 and $15 \mathrm{~d}$ after germination) with glass chimney and the number of such whiteflies used were at the rate of $2,4,6,8,10,12,14$ and 20 adults per plant. Observations were made on the virus symptom expression $30 \mathrm{~d}$ after challenge. The efficiency of transmission was determined. The efficiency of transmission of OELCV was the highest (maximum T and $\mathrm{P}^{*}, 0.80,1.00$ and $0.08,0.10$ ) when $7 \mathrm{~d}$ old seedlings were inoculated (Arka anamika and $A E 64$ respectively) and transmission had decreased as the age of seedlings increased. The estimated transmission rate for single whitefly $\left(\mathrm{P}^{*}\right)$ increased with an increase in the number of whiteflies used per plant. Okra plant resistance to $B$. tabaci significantly changed the transmission rates of OELCV on okra. Understanding the resistance mechanisms of the okra accessions and interactions between plant viruses and their insect host can pave the way for novel approaches to protect plants from virus infection.
\end{abstract}

Keywords: Bemisia tabaci, Okra, Okra enation leaf curl virus, Transmission rate, Whitefly

\section{INTRODUCTION}

India is the world's leading producer of okra, Abelmoschus esculentus (L.) Moench with the production of 6095 thousand $\mathrm{mt}$ from an area of 509 thousand mha (Horticultural Statistics at a Glance, 2018). Okra is an important source of vitamins, calcium, potassium, and other minerals, which are often lacking in people's diet in developing countries (Singh et al., 2014). The crop is prone to damage by various insects, fungi, nematodes and viruses, although its degree of infestation varies widely. The production and quality of okra fruits are affected by an array of sucking and fruit boring pests from the seedling phase until harvest. The key sucking 
insect pests of okra are whiteflies, aphids, jassids, thrips and mites (Anitha and Nandihalli, 2008). Among the sucking pests, the sweet potato whitefly, Bemisia tabaci (Gennadius) (Aleyrodidae: Hemiptera) causes damage directly through feeding and indirectly by the transmission of viruses. The whitefly transmits important begomoviruses in okra such as bhendi yellow vein mosaic virus (BYVMV) and okra enation leaf curl virus (OELCV). The incidence of OELCV has reached serious proportions in recent years both in Northern India (Sanwal et al., 2016) and Southern India as well (Sayed et al., 2014).Host plant resistance is an economically sound and ecologically safe method for managing insect pests including $B$. tabaci (Hilje et al., 2001). Our earlier studies involving field screening of 88 okra germplasm against the sweet potato whitefly, $B$. tabaci and the begomoviruses, Okra enation leaf curl virus (OELCV) and Bhendi yellow vein mosaic virus (BYVMV) during two seasons (March, June sowing) of 2018 at Attur, Salem District, Tamil Nadu revealed that the lowest mean population of whiteflies was recorded in the okra accessions viz.,Upl mona 2 (0.35), Co 1 (0.4), A. moschattus (0.65), Sona (0.78). In contrast, accessions AE 66, IC 113920 and IC 282274 recorded the highest number of whiteflies with a mean population of 3.94, 3.45 and 3.24 adults per leaf (Pasupathi et al., 2019). Among the accessions tested, A. moschattus and Upl mona 2 did not show any signs of OELCV and BYVMV infection throughout the crop period. The highest OELCV per cent disease incidence (PDI) was recorded on AE 66 (100) followed by AE 64 (80) and AE 65 (80), while the PDI recorded susceptible check was $100 \%$ (Pasupathi et al., 2019). The OELCV infected young leaves of selected okra accessions were collected from the screening field and was analyzed using DNA marker specific to coat protein-based primer in polymerase chain reaction (PCR) and the amplicons were sequenced and comparative analysis had confirmed the OELCV (data unpublished) (Pasupathi, 2020). It is important to understand the interactions between the host plants, their age, the insect resistance nature of the host plants, and vectoring insects to develop field management strategies. Thus, the current research was taken up with the aim of establishing information on interactions between the $B$. tabaci adults, okra plant age and resistance; and the OELCV under laboratory condition.

\section{MATERIALS AND METHODS}

\section{Test plants}

The seeds of okra accessions viz.,Upl mona 2 (Highly resistant), Co 1 (Moderately resistant), Arka anamika (Moderately susceptible) and AE 64 (Highly susceptible)were selected from the field screening reactions to whitefly and OELCV responses. Plants were grown in coco pith and soil potting mix in $13 \mathrm{~cm}$ dia $\times 15 \mathrm{~cm}$ height mud pots and maintained at a $30-35^{\circ} \mathrm{C}$ temperature and $70-80 \%$ of relative humidity in walk-in-cages in the Insectary at the Agricultural College and Research Institute, Tamil Nadu Agricultural University (TNAU), Madurai.

\section{Insect culture}

Adults of cotton whitefly, B. tabaci were collected from okra (A. esculentus L.) and cotton (Gossypium spp.) in Madurai district of Tamil Nadu, India and were cultured on mixed host plants of cotton (cultivar ARBH 1401), Black night shade (Solanum nigrum) and Okra (A. esculentus) in the greenhouse.

\section{Virus source}

Symptomatic Okra plants were collected by uprooting (with minimum disturbance to the taproot system and the soil around the roots is intact) from five locations (farmer fields) in and around Attur, Salem district, Tamil Nadu, India. These plants served as the inoculum source and further inoculated on the susceptible check (OELCV check) and used for transmission studies. Initially, the virus presence was molecularly confirmed by PCR using specific primers (JKOE34F5'AAGAATTATGTCGAAGCGTCCTGCTT-3' (Forward primer) and JKOE35R 5'-AAGAATCGTAGAAGTAA CTCCTAACTT-3' (Reverse primer) (Rakesh Kumar, 2016) (Fig. 1).

\section{Effect of okra plant age on OELCV transmission by B. tabaci}

To perform the experiment, Okra plant (30-d-old) with typical OELCV symptom from the virus culture source plants was selected and caged individually so that the space around the plant inside the cage was very close to minimal. Whiteflies (adults) were collected from healthy culture and were introduced at the rate of 100 125 numbers of adults/OELCV infected okra plant. They were left undisturbed for $24 \mathrm{hr}$ with a buffer time of $2 \mathrm{hr}$ allowed for settling by the adults. After $24 \mathrm{hr}$, these adults were collected in test tubes at the rate of 10 numbers per tube, starved for $1 \mathrm{hr}$ and were used for challenging on the test accessions. The test accessions were raised in $13 \mathrm{~cm}$ dia $\times 15 \mathrm{~cm}$ height mud pots filled with coco pith mixed soil, nourished with fertilizers and regularly watered. Differentially aged seedlings ( 7 , 10 and $15 \mathrm{~d}$ after germination) obtained by staggered showing with uniformity in leaf size and shape at respective ages were independently caged with a glass chimney $(6.5 \mathrm{~cm}$ dia $\times 15 \mathrm{~cm}$ height). Care was taken that the selected plants were free from any insect damage and life stages of insects. Then, the whiteflies in the test tubes were carefully released inside the glass chimney @10 OELCV viruliferous B. tabaci per plant. Five replications were maintained in each age group 
and each plant was considered as single replication. Insects were given a $24 \mathrm{hr}$ acquisition access period (AAP) on OELCV expressed plants and an inoculation access period (IAP) on test accessions with an additional buffer time of $2 \mathrm{hr}$ for settling on plants. After the IAP, the glass chimney were opened and the whiteflies were removed and the plants were treated with insecticide solution to destroy life stages of the insects, if any and were further mobilized into bigger cages $(60 \mathrm{~cm} \times 60 \mathrm{~cm} \times 60 \mathrm{~cm})$ fitted with 100 micron mesh all around for observation. The plants were observed for symptom development30 d after removal from the glass chimney and the transmission rate was calculated. The OELCV specific PCR was used to test the plants for confirmation of the virus incidence.

Effect of vector load against whitefly resistant accessions on OELCV disease transmission by $B$. tabaci

Viruliferous adult $B$. tabaci were prepared as described in the previous section. After $24 \mathrm{hr}$, these adults were collected in test tubes at the rate of $2,4,6,8,10,12$, 14 and 20 in individual glass tubes and were used to challenge on the test accessions (Upl mona 2, Co 1,
Arka anamika and AE 64) which were individually caged (7 to 10-d-old) with glass chimney. This set up was left undisturbed for $24 \mathrm{hr}$ and then the cages were opened and whiteflies were disturbed by slightly shaking the plants and ensured that no insects were settled on plants and an insecticide spray was given to kill life stages if remained any. These plants were kept inside $150 \mathrm{~cm} \times 150 \mathrm{~cm} \times 150 \mathrm{~cm}$ cages fitted with transparent 100 micron mesh cloth for one month for symptom development. Five replications were used and a single plant served as a replicate. The development of disease symptoms and confirmation using PCR was done as described in the previous section.

\section{Estimation of transmission rate}

The transmission rates were calculated by dividing the number of infected plants by the number of inoculated plants and estimated transmission rate. The transmission rate of a single whitefly was calculated as follows using the formula of (Gibbs and Gower, 1960).

$$
P^{*}=\frac{1-(1-T) 1}{1} \times 100
$$

Where, $\mathrm{P}^{*}=$ estimated transmission rate for a single whitefly; $T=$ transmission rate $T=R / N ; R=$ number of in-

Table 1: Effect of age and whitefly resistance response of the okra genotype plants on transmission of OELCV by B. tabaci adults.

\begin{tabular}{|c|c|c|c|c|c|}
\hline $\begin{array}{l}\text { Age of plants } \\
\text { (d after ger- } \\
\text { mination) }\end{array}$ & Accessions & $\begin{array}{l}\text { Whitefly re- } \\
\text { sistance response } \\
\text { of genotype }\end{array}$ & $\begin{array}{l}\text { Plants infected } \\
\text { (R)/plants } \\
\text { inoculated (N) }\end{array}$ & $\begin{array}{l}\text { Transmission } \\
\text { Rate }(T=R / N)\end{array}$ & $\begin{array}{l}\text { Estimated Transmis } \\
\text { sion rate for single } \\
\text { whitefly }\left(P^{*}\right)\end{array}$ \\
\hline \multirow{4}{*}{7} & Upl mona 2 & Highly Resistant & $0 / 5$ & $\begin{array}{l}0.00 \\
(0.50)^{a}\end{array}$ & 0.00 \\
\hline & Co 1 & $\begin{array}{l}\text { Moderately Re- } \\
\text { sistant }\end{array}$ & $2 / 5$ & $\begin{array}{l}0.40 \\
(0.90)^{\mathrm{b}}\end{array}$ & 0.04 \\
\hline & Arka anamika & $\begin{array}{l}\text { Moderately Sus- } \\
\text { ceptible }\end{array}$ & $4 / 5$ & $\begin{array}{l}0.80 \\
(1.30)^{c}\end{array}$ & 0.08 \\
\hline & AE 64 & Highly Susceptible & $5 / 5$ & $\begin{array}{l}1.00 \\
(1.50)^{c}\end{array}$ & 0.10 \\
\hline \multirow{4}{*}{10} & Upl mona 2 & Highly Resistant & $0 / 5$ & $\begin{array}{l}0.00 \\
(0.50)^{a}\end{array}$ & 0.00 \\
\hline & Co 1 & $\begin{array}{l}\text { Moderately Re- } \\
\text { sistant }\end{array}$ & $1 / 5$ & $\begin{array}{l}0.20 \\
(0.70)^{a}\end{array}$ & 0.02 \\
\hline & Arka anamika & $\begin{array}{l}\text { Moderately Sus- } \\
\text { ceptible }\end{array}$ & $3 / 5$ & $\begin{array}{l}0.60 \\
(1.10)^{b}\end{array}$ & 0.06 \\
\hline & AE 64 & Highly Susceptible & $5 / 5$ & $\begin{array}{l}1.00 \\
(1.50)^{b}\end{array}$ & 0.10 \\
\hline \multirow{6}{*}{15} & Upl mona 2 & Highly Resistant & $0 / 5$ & $\begin{array}{l}0.00 \\
(0.71)^{a}\end{array}$ & 0.00 \\
\hline & Co 1 & $\begin{array}{l}\text { Moderately Re- } \\
\text { sistant }\end{array}$ & $1 / 5$ & $\begin{array}{l}0.20 \\
(0.83)^{\mathrm{ab}}\end{array}$ & 0.00 \\
\hline & Arka anamika & $\begin{array}{l}\text { Moderately Sus- } \\
\text { ceptible }\end{array}$ & $1 / 5$ & $\begin{array}{l}0.40 \\
(0.94)^{b}\end{array}$ & 0.00 \\
\hline & AE 64 & Highly Susceptible & $2 / 5$ & $\begin{array}{l}0.40 \\
(0.94)^{b}\end{array}$ & 0.02 \\
\hline & & & & SEd & 0.1154 \\
\hline & & & & CD (.05) & 0.2663 \\
\hline
\end{tabular}

Values in parentheses are square root transformed, *Means in a column followed by the same letter are not significantly different $(\alpha=$ 0.05) by Tukey's HSD test 
Pasupathi, E. et al. / J. Appl. \& Nat. Sci. 13 (SI), 63 - 68 (2021)

Table 2: Transmission rate of OELCV on different okra accessions with differential whitefly resistance responses with varying challenged numbers of $B$. tabaci under laboratory condition.

\begin{tabular}{|c|c|c|c|c|}
\hline Accessions & $\begin{array}{l}\text { Number of White- } \\
\text { flies used (I) }\end{array}$ & $\begin{array}{l}\text { Plants infected (R)/ } \\
\text { Plants inoculated (N) }\end{array}$ & $\begin{array}{l}\text { Estimated Transmission } \\
\text { rate for single whitefly }\left(P^{*}\right)\end{array}$ & $\begin{array}{l}\text { Transmission } \\
\text { Rate }(T=R / N)\end{array}$ \\
\hline Upl mona 2 & 0 & $0 / 5$ & 0 & $0.00(0.50)^{\mathrm{a}}$ \\
\hline Upl mona 2 & 2 & $0 / 5$ & 0 & $0.00(0.50)^{\mathrm{a}}$ \\
\hline Upl mona 2 & 4 & $0 / 5$ & 0 & $0.00(0.50)^{\mathrm{a}}$ \\
\hline Upl mona 2 & 6 & $0 / 5$ & 0 & $0.00(0.50)^{\mathrm{a}}$ \\
\hline Upl mona 2 & 8 & $0 / 5$ & 0 & $0.00(0.50)^{\mathrm{a}}$ \\
\hline Upl mona 2 & 10 & $0 / 5$ & 0 & $0.00(0.50)^{\mathrm{a}}$ \\
\hline Upl mona 2 & 12 & $0 / 5$ & 0 & $0.00(0.50)^{a}$ \\
\hline Upl mona 2 & 14 & $0 / 5$ & 0 & $0.00(0.50)^{\mathrm{a}}$ \\
\hline Upl mona 2 & 20 & $0 / 5$ & 0 & $0.00(0.50)^{\mathrm{a}}$ \\
\hline Co 1 & 0 & $0 / 5$ & 0 & $0.00(0.50)^{\mathrm{a}}$ \\
\hline Co 1 & 2 & $1 / 5$ & 0.1 & $0.20(0.70)^{b}$ \\
\hline Co 1 & 4 & $2 / 5$ & 0.1 & $0.40(0.90)^{\mathrm{bc}}$ \\
\hline Co 1 & 6 & $0 / 5$ & 0 & $0.00(0.50)^{\mathrm{a}}$ \\
\hline Co 1 & 8 & $1 / 5$ & 0.02 & $0.20(0.70)^{b}$ \\
\hline Co 1 & 10 & $0 / 5$ & 0 & $0.00(0.50)^{\mathrm{a}}$ \\
\hline Co 1 & 12 & $2 / 5$ & 0.03 & $0.40(0.90)^{\mathrm{bc}}$ \\
\hline Co 1 & 14 & $0 / 5$ & 0 & $0.00(0.50)^{\mathrm{a}}$ \\
\hline Co 1 & 20 & $2 / 5$ & 0.02 & $0.40(0.90)^{\mathrm{bc}}$ \\
\hline Arka anamika & 0 & $0 / 5$ & 0 & $0.00(0.50)^{\mathrm{a}}$ \\
\hline Arka anamika & 2 & $1 / 5$ & 0.1 & $0.20(0.70)^{b}$ \\
\hline Arka anamika & 4 & $2 / 5$ & 0.1 & $0.40(0.90)^{\mathrm{bc}}$ \\
\hline Arka anamika & 6 & $2 / 5$ & 0.06 & $0.40(0.90)^{\mathrm{bc}}$ \\
\hline Arka anamika & 8 & $3 / 5$ & 0.07 & $0.60(1.10)^{c d}$ \\
\hline Arka anamika & 10 & $3 / 5$ & 0.06 & $0.60(1.10)^{c d}$ \\
\hline Arka anamika & 12 & $4 / 5$ & 0.06 & $0.80(1.30)^{\mathrm{de}}$ \\
\hline Arka anamika & 14 & $5 / 5$ & 0.07 & $1.00(1.50)^{\mathrm{e}}$ \\
\hline Arka anamika & 20 & $5 / 5$ & 0.05 & $1.00(1.50)^{\mathrm{e}}$ \\
\hline AE 64 & 0 & $0 / 5$ & 0.00 & $0.00(0.50)^{\mathrm{a}}$ \\
\hline AE 64 & 2 & $2 / 5$ & 0.20 & $0.20(0.70)^{b}$ \\
\hline AE 64 & 4 & $2 / 5$ & 0.10 & $0.20(0.70)^{b}$ \\
\hline AE 64 & 6 & $3 / 5$ & 0.10 & $0.60(1.10)^{c d}$ \\
\hline AE 64 & 8 & $3 / 5$ & 0.07 & $0.60(1.10)^{\mathrm{cd}}$ \\
\hline AE 64 & 10 & $4 / 5$ & 0.08 & $0.80(1.30)^{\mathrm{de}}$ \\
\hline AE 64 & 12 & $5 / 5$ & 0.08 & $1.00(1.50)^{\mathrm{e}}$ \\
\hline AE 64 & 14 & $5 / 5$ & 0.07 & $1.00(1.50)^{\mathrm{e}}$ \\
\hline \multirow[t]{3}{*}{ AE 64} & 20 & $5 / 5$ & 0.05 & $1.00(1.50)^{\mathrm{e}}$ \\
\hline & & & SEd & 0.0788 \\
\hline & & & $\mathrm{CD}(.05)$ & 0.1563 \\
\hline
\end{tabular}

Values in parentheses are square root transformed, *Means in a column followed by the same letter are not significantly different $(\alpha=$ $0.05)$ by Tukey's HSD test

fected plants; $N=$ number of receptor plants; I=number of whiteflies per receptor plant.

\section{Statistical analysis}

Data from transmission experiments were analyzed using a one-way analysis of variance (ANOVA) (SAS Institute, 1985) and the transmission rates were transformed into $\sqrt{x+0.5}$ before statistical analysis. The Means in a column followed by the same letter are not significantly different $(\alpha=0.05)$ by Tukey's HSD test.

\section{RESULTS AND DISCUSSION}

\section{Effect of age of the seedlings on transmission OELCV by B. tabaci}

The age of okra plants had a profound impact on the vector transmission (Table 1). The transmission efficiency was the highest (maximum $T$ and $P^{*}, 0.80,1.00$ 
Pasupathi, E. et al. / J. Appl. \& Nat. Sci. 13 (SI), 63 - 68 (2021)

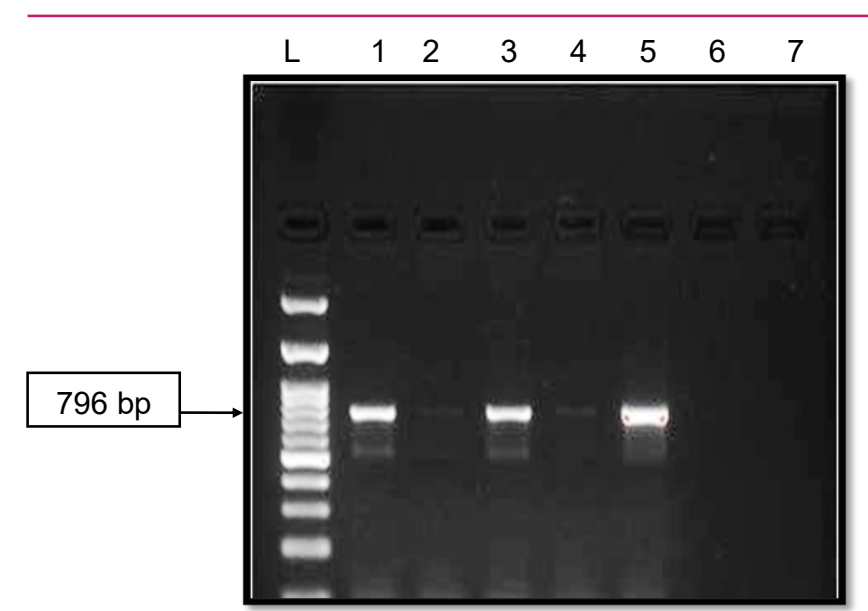

Fig. 1. Polymerase chain reaction amplification of the part of OELCV coat protein gene using specific primers on DNA from leaf samples of okra accessions collected from Attur, Salem district, Tamil Nadu. Lane L - Marker (100 bp Ladder), Lane 1-7 - Samples.

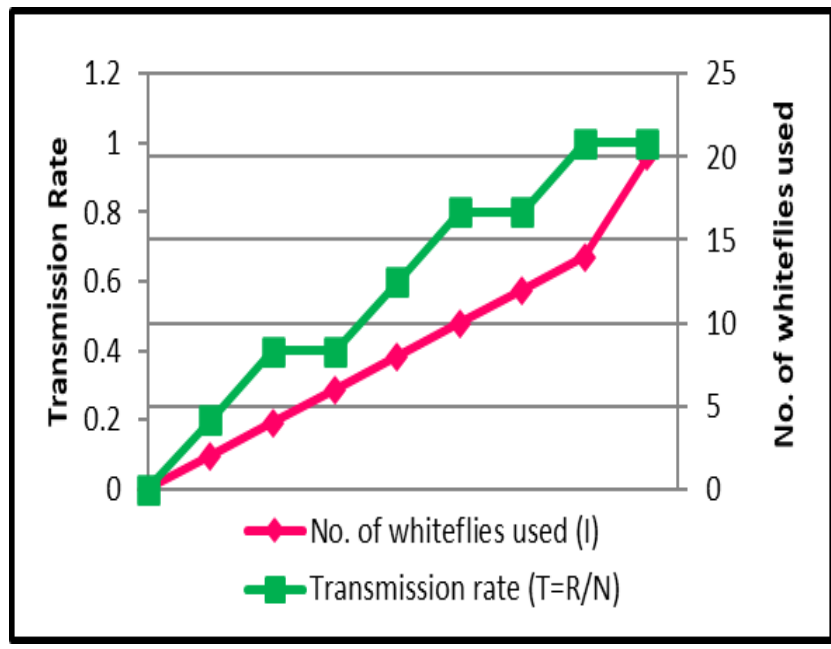

Fig. 2. Determination of minimum numbers of $B$. tabaci for effective transmission of OELCV on whitefly susceptible $A E 64$.

and $0.08,0.10$ ) when $7 \mathrm{~d}$ old seedlings were inoculated (Arka anamika and AE 64 respectively) and transmission had decreased as the age of seedlings increased. Accessions, Upl mona 2 and Co 1 had acquired the lowest transmission when $7 \mathrm{~d}$ old seedlings were inoculated (minimum $\mathrm{T}$ and $\mathrm{P}^{*}, 0.00,0.40$ and $0.00,0.04)$. Thus, Arka anamika and AE 64 were considered as susceptible to OELCV and Upl mona 2 and Co 1 were considered as highly resistant as similar to field screening. The present study results were in line with Venkataravanappa et al. (2015), who found that the age of seedlings used for transmission offered a negative correlation with transmission efficiency and the transmission was increased as the age of seedlings decreased on okra seedlings while $B$. tabaci was engaged in the transmission of okra enation leaf curl disease.
Transmission rate of OELCV on different okra accessions with varying challenged numbers of $B$. tabaci under laboratory condition

The insect transmission levels had significantly varied among the okra accessions, minimum of two whiteflies per okra plant was found to be effective for virus transmission, with typical symptoms appearing after a minimum incubation period of 10-12 d under caged conditions. The transmission rate $(T)$ was higher on accessions AE 64 followed by Arka anamika whereas the lower transmission rates were observed on accessions Upl mona 2 and Co 1 (Table 2). The transmission rate (T) and estimated transmission rate for single whitefly $\left(P^{*}\right)$ increased with an increase in number of whiteflies per plant used. The accession Upl mona 2 showed no transmission with 4 numbers of whiteflies, whereas the accession AE 64 had a transmission rate (0.20) with 4 numbers of whiteflies (Fig. 2). The increase in numbers of challenged whiteflies led to a higher rate of OELCV disease transmission in different varieties. In the case of Arka anamika and $A E 64$ the transmission rate was $0.60,1.00$ and 1.00 with 8, 14 and 20 numbers of whitefly/plant, respectively. Venkataravanappa et al. (2015), reported that the number of whiteflies used in transmission and the increase in AAP or IAP had a positive correlation with transmission efficiency and thus increased $T$ and $P^{*}$ values. Similarly, Senanayake et al., (2012) found that eight whiteflies per plant were sufficient to produce $100 \%$ transmission of chilli leaf curl virus on Capsicum spp. and the inoculated plants had developed symptoms within 7-10 d post inoculation. Venkataravanappa et al. (2017), while studying the $B$. tabaci genetic species (MEAM- 1 and Asia-1) and OYVMD interactions had indicated that a minimum of two and three adult $B$. tabaci per plant respectively, were necessary to transmit the disease. The minimum IAP differed among MEAM- 1 (15 min.) and Asia-1 (20 min.) whitefly population to transmit the OYVMD.

\section{Conclusion}

In India, the okra crop is highly susceptible to BYVMV and OELCV disease, probably due to the warm tropical climate and intensive and continuous crop cultivation, which supports the whitefly population's survival round the year. In the present study, the efficiency of transmission of OELCV was the highest (maximum $\mathrm{T}$ and $\mathrm{P}^{*}, 0.80,1.00$ and $0.08,0.10$ ) when $7 \mathrm{~d}$ old seedlings were inoculated (Arka anamika and AE 64 respectively). Host plant resistance to the virus is one of the most practical, economical and environmentally friendly strategies for reducing yield loss in okra. Understanding the resistance mechanisms of the okra accessions and interactions between plant viruses and their insect host can pave the way for novel approaches to protect 
plants from virus infection. This phenomenon needs to be explored in the near future.

\section{Conflict of interest}

The authors declare that they have no conflict of interest.

\section{REFERENCES}

1. Anitha, K. \& Nandihalli, B. (2008). Seasonal incidence of sucking pests in okra ecosystem. Kar. J. Agri. Sci., 21 (1), 137-138.

2. Gibbs, A. \& Gower, J. (1960). The use of a multiple transfer method in plant virus transmission studies-some statistical points arising in the analysis of results. Annals of Appl. Bio., 48 (1), 75-83.

3. Hilje, L., Costa, H.S. \& Stansly, P.A. (2001). Cultural practices for managing Bemisia tabaci and associated viral diseases. Crop Protec., 20 (9), 801-812.

4. Horticultural Statistics at a Glance (2018). Horticulture Statistics Division, Department of Agriculture, Cooperation and Farmers Welfare, Ministry of Agriculture and Farmers Welfare, Government of India.

5. Pasupathi, E., Murugan, M., Harish, S. \& Chinnaiah, C. (2019). Screening of okra germplasm for resistance to whitefly, Bemisia tabaci and okra enation leaf curl virus (OELCV) under field conditions. J. of Phar. and Phytoche., 8(5), 2306-2313.

6. Pasupathi, E. (2020). Understanding the capabilities of whitefly Bemisia tabaci in transmission of okra enation leaf curl virus (OELCV) in bhendi Abelmoschus esculentus and their management. Ph. D. Thesis, Tamil Nadu Agrl. Univer., Coimbatore (India).
7. Rakesh Kumar, V.R. (2016). Global prospectives in virus disease management, Inter. con: virocon. Bengeluru, India.

8. Sanwal, S., Venkataravanappa, V. \& Singh, B. (2016). Resistance to bhendi yellow vein mosaic disease: a review. Ind. J. Agr. Sci., 86, 835-843.

9. SAS Institute (1985). SAS users guide: basics. SAS Inst., Cary, NC.

10. Sayed, S., Rana, D., Krishna, G., Reddy, P. \& Bhattacharya, P. (2014). Association of Begomovirus with Okra (Abelmoschus esculentus L.) leaf curl virus disease in southern India. SAJ Biotech., 1(102), 2-2.

11. Senanayake, D., Varma, A. \& Mandal, B. (2012). Virusvector relationships, host range, detection and sequence comparison of chilli leaf curl virus associated with an epidemic of leaf curl disease of chilli in Jodhpur, India. J. Phyto Patho., 160 (3), 146-155.

12. Singh, P., Chauhan, V., Tiwari, B., Chauhan, S.S., Simon, S., Bilal, S. \& Abidi, A. (2014). An overview on okra (Abelmoschus esculentus) and it's importance as a nutritive vegetable in the world. Int. J. of Phar. and Bio. Sci., 4 (2), 227-233.

13. Venkataravanappa, V., Reddy, C.L., Jalali, S., Briddon, R.W. \& Reddy, M.K. (2015). Molecular identification and biological characterisation of a begomovirus associated with okra enation leaf curl disease in India. Euro. J. of PI. Patho., 141(2), 217-235.

14. Venkataravanappa, V., Kodandaram, M., Reddy, C.L., Shankarappa, K. \& Reddy, M.K. (2017). Comparative transmission of Bhendi yellow vein mosaic virus by two cryptic species of the whitefly, Bemisia tabaci (Hemiptera: Aleyrodidae). 3 Biotech., 7 (5), 331. 